\title{
ENTER THE CLOWNS: ADAPTING SHAKESPEARE AFTER 1642
}

\author{
KLÁRA ŠKROBÁNKOVÁ \\ Masaryk University
}

\begin{abstract}
This paper focuses on the genre of drolls as they were compiled in Francis Kirkman's collection The Wits or Sport upon Sport, published in 1672 and 1673. The anthology includes scenes from Hamlet or A Midsummer Night's Dream and draws upon characters like Falstaff and others. By description and analysis of these dramatic pieces, I would like to draw one's attention to the genre that is almost unknown to the history of English speaking drama. This article focuses on the process of rethinking Shakespeare so as not only to entertain people in the critical period of English history, but also to preserve the dramatic conventions that William Shakespeare and his contemporaries created. It also considers the changes the authors of the drolls made when adapting the parent plays of William Shakespeare.
\end{abstract}

Keywords: The Wits, Francis Kirkman, adaptation, Interregnum, theatre, Falstaff

The Wits or Sport upon Sport is a collection of short farces and drolls, which was published between the years 1662 and 1673. Overall, three editions of the collection exist - the first part was printed in octavo in 1662 by Henry Marsh, followed by the second edition of the same first part in 1672 by Francis Kirkman, a co-worker of Marsh. A year later, in 1673, Kirkman printed the long proclaimed second part of The Wits, both in quarto and octavo (Elson 1).

There are almost no differences between the two editions of the first part - the only change is in the tone of the preface to the collection. The author of the 1662 preface is Marsh, posing as a mere "compiler", seeking profit and by no means fame (1). The writing presents itself as very modest, reserved and apologetic - Marsh apologizes for any mistakes in the volume, and assures the reader that there were more people than himself who saw the publishing of these drolls as a respectable thing to do: "I was told by people that know better than myself, they would be in this model more beneficial in sundry respect, then as they lay dispersed before" (Marsh's Preface A2v). 
Marsh's introduction ends with the appeal to "remember the rump drolls", emphasizing the fragmental quality of the collection, suggesting that there used to be many more of such farcical scenes, which unfortunately did not survive in a written form. Marsh's 'serious' informative approach is particularly interesting if compared to the prefaces written by Francis Kirkman. Kirkman's persona is more of a "jolly fellow" - he often describes humorous stories and makes it seem as if he had seen the majority of the drolls he is publishing. He, however, reprints Marsh's preface to the first part of The Wits word-by-word, making only two changes. He omits the mention of the "rump drolls" and he also signs the preface with his own name, putting his predecessor completely out of the picture.

Little is known about Henry Marsh. He was a London-based bookseller, having his shop near Chancery Lane. He probably died "before the end of the year 1665", allegedly of plague, with Kirkman taking over his business later that year (Plomer 123).

There is considerably more information about Francis Kirkman, as he himself shared facts from his life in prefaces to various books he was printing. Born in 1632, the son of a London blacksmith, he initially worked as a scrivener. In 1656, he established himself as a bookseller but had to return to his job as scrivener due to "having knaves to deal with" (Plomer 110). After the Restoration he returned to West End, working both as a scrivener and bookseller. Following some time working with Marsh, he inherited his shop probably because of Marsh's debts to Kirkman (Plomer 111).

From his childhood, Francis Kirkman was known to be "a collector of plays", writing a dedicatory epistle to an edition of Marlowe's Lust's Dominion (Plomer 110-11). His involvement with theatre led to the publication of the Catalogue of all the English Stage-Playes that were printed since the beginning of the Elizabethan era, containing 690 items. The updated edition, published ten years later, contained 806 entries (Goodwin 219). The Dictionary of National Biography says that "in an interesting 'Advertisement' he [Kirkman] informs his readers that he had not only seen but had read all these plays, and possessed most of them, which he was ready either to sell or lend upon reasonable considerations" (219). Elson supposes that Kirkman might have been on the Continent during the Civil War, as he was able to speak and translate from both French and Spanish, but such information cannot be verified (Elson 7). He probably died sometime after the year 1680, when he stopped publishing (Elson $11)$.

Apart from the historically uncertain details about the relationship between Kirkman and Marsh, the prefaces to both volumes of The Wits contain a lot of interesting information about the conventions of the genre. Let us consider, for instance, Marsh's observation, published in 1662 and reprinted verbatim by Kirkman ten years later: "He that knows a play, knows that 
humours have no such fixedness and indissoluble connexion to the design, but that without injury or forcible revolution, they may be removed to an advantage" (Marsh's Preface, not numbered). Such declaration proves to be a justification of what the mostly anonymous authors of the drolls were doing - simply taking the comical scenes and sketches out of the well-known Elizabethan, Jacobean or Caroline plays and performing them (or in Kirkman's and Marsh's case, printing them).

Interestingly enough, neither Marsh nor Kirkman mentions the names of the original authors, even though they provide the reader of the first part with the list of drolls and the corresponding plays. The reasons for the omission of the names are uncertain. Kirkman, however, lists some of the names in the preface to the second volume of The Wits, where he says that "the most part of these pieces were written by such penmen as were known to be the ablest artists that ever this nation produced, by name, Shake-spear, Fletcher, Johnson, Shirley, and others" (Kirkman A2r). Yet this is at least peculiar - in the second part of The Wits, there is only a droll The Merry Conceited Humours of Bottom the Weaver, an adaptation of Shakespeare's Midsummer's Night Dream, and no droll inspired by either Fletcher, Johnson or Shirley. There are indeed drolls adapted from these authors in the first Wits, but the preface does not reference this volume at all.

This might be seen as a marketing trick of Kirkman - surely, mentioning the names of important playwrights sounded much more attractive to potential readers than publishing a collection of anonymous sketches. Francis Kirkman surely did everything he could to promote his book. In the preface to the 1673 edition, he recommends the book to a wide variety of readers, even to the "merry saylors in long voyage, to the East or West Indies" (Kirkman A5v).

Beyond the tricks of the trade, Kirkman nevertheless shares a lot of valuable information about which drolls were performed during the twenty years of puritan interregnum and civil war and gives much useful detail about the productions. He claims that he will share "his experience", putting himself in the position of the eye witness of the period, which is a very different approach from Marsh's very distanced one (Kirkman A2r). Kirkman primarily explains the reasons for choosing the format of short sketches and excerpts: "When the publique theatres were shut up, and the actors forbidden to present us with any of their tragedies, because we had enough of that in earnest, and comedies, because the vices of the age were too lively and smartly represented. Then all that we could divert our selves with were these humours and pieces of plays" (A3v).

The drolls are here portrayed as an immediate response to the political situation in England after 1642 tragedies or comedies could not be performed in the playhouses, so the actors had to invent a new form. Kirkman's commentary about the inappropriateness of tragedy at a time when war raged in England 
sheds some light on the absence of some popular plays from the preceding era say tragedies by Shakespeare, Webster or Ford. As for the comedies, it is understandable that comic relief should be the easiest and most popular form of entertainment, but the selected drolls are not merely a collection of silly slapstick pieces intended for laughter only.

Even though some scholars claim that the drolls were absolutely apolitical, various references made by Kirkman in this preface and some selected pieces of drollery prove otherwise. Elson, for example, writes that "no contemporary political allusions occur in the drolls; no interpolations are made to satirize contemporary happenings, and very few excisions can be detected of passages which might be thought to touch on dangerous current issues" (22). It is true that The Wits are not a collection of satirical scenes about Cromwell, puritans or royalists, but it is certainly not a coincidence that a significant portion of the drolls employ the character of the soldier as the main protagonist One would hardly look for some straightforward statements commenting the political situation, but very subtle criticism is discernible throughout both parts of the collection. The particular political implications of certain drolls will be explained in what follows.

Kirkman's slightly negative portrayal of the civil war and interregnum period is emphasized in the passage where he talks about the costumes used during the performances of drolls. He ridicules the British army and quotes a famous passage from Fletcher's comedy The Woman's Prize, "Enter the Red Coat, exit hat and cloak", pointing out the common practice of the authorities to confiscate the costumes, thus preventing the company to perform (Kirkman, A4v). Kirkman also asserts that the actors were not only stripped of their clothes, but that they were "many times imprisoned, till they paid such ransom as the souldiers would impose upon them" (A4v). This unfortunate position of the performers was bypassed by using ordinary clothes adjusted to look luxurious.

The provisional conditions of the performances apparently did not prevent the actors from dressing up and putting on a playlet that would need good-looking garments: "It was hazardous to act any thing that required any good cloaths, instead of which painted cloaths many times served the turn to represent rich habits" (A4v). This remark helps to imagine the actual scenic aspect of the sketches - there were some costumes or at least something that would clearly and visually separate them from everyday reality. Kirkman mentions that the actor Robert Cox used buttered bread as a prop for the droll about the ever-so-famous Simpleton, which also proves the employment of certain, even though surely primitive, props. For example, in the droll "The Grave-makers Argument", the audience should see a grave maker about to dig a grave; it would, indeed, be natural if the performer was holding a tool of some sort. The use of props and costumes on the "stage" will be further analysed in the paragraphs focusing on the certain drolls. 
The above-mentioned actor Robert Cox is the only known author of a number of drolls featured in Kirkman's and Marsh's collection. Kirkman names him in the 1673 preface: "the incomparable Robert Cox, who was not only the principal actor, but also the contriver and author of most of these farces" (Kirkman A3v). Cox is surely the author of the drolls "Oenone" and "Acteon and Diana" because these were printed individually before being published in the collection of The Wits. The little booklet of the drolls, published under the title Acteon and Diana, was printed a year after Cox's death (1656). The title page of the collection reads: "Acteon \& Diana with a Pastoral Storie of the Nimph Oenone. Followed by the several conceited humours of Bumpkin the Huntsman, Hobbinal the Shepherd, Singing Simpkin, and Iohn Swabber the Seaman" (Cox, not numbered). The author is "Rob. Cox" and the drolls in the book are claimed to be "acted at the Red Bull with great applause". This information coincides with the one provided by Kirkman - Cox was a successful droll-performer, who acted in many scenes. The nature of the pieces in Acteon differs greatly, stretching from farcical drolls to short pastorals - yet, this confirms the eclecticism of the period as The Wits share this variability of style.

Apart from the quoted details, not much is known about Robert Cox and his life. Both Randall and Elson suspect that he was a strolling player who probably did not belong to any London-based group of actors, but had been touring the country performing various repertoire (Randall 151). He was undoubtedly arrested in 1653 while performing "John Swabber the Seaman". The story was described in the weekly issue of Mercurius Democritus:

The Rope dancers having implyed one Mr. Cox an Actor, (a very honest though impoverished man, who is not only as well as others, put by the practice of his Calling, but charged with a poor Wife, and 5 helpless Infants) to present a modest and ha[r]mless jigge, calle[d] Swobber, yet two of his own quality, envying their poor brother should get a little bread for his Children, basely and unworthily betrayed him to the Souldie[r]s, and so abused many of the Gentry that formerly had been their Benefactors, who were forced to play to the Souldiers 5 s. a piece for their coming out, as well as for their going in. (Democritus 463)

The short report contains some very interesting remarks: firstly, there is the information about the rivalry between the actors, who were willing to report their colleague out of jealousy. Such a claim obviously cannot be confirmed but the competitiveness of actors, performers and troupes is such a widespread phenomenon that the denunciation of Cox seems to be highly probable. Another, more important piece of information is the word "gentry" used in the account, which tells us more about the people who were coming to see the shows. Even though performances of drolls were on the edge of legality, the audience consisted not only of common people, but also of members of the upper classes. 
Finally, the monetary value of one show can be noticed in the testimony - five shillings per person may not have been enough for the actor to live comfortably (given the need to provide a certain amount of the money to the owner of the place where the show had taken place), but it surely must have been a nice sum for the soldiers who were closing the place down. Rollins thinks that "the soldiers connived at acting only when to do so was to their own financial advantage" (Rollins 311).

Nevertheless, these fragments of information are among the few that help with the reconstruction of who Robert Cox was. Otherwise, it is known that he died on December 12, 1655, making the publication of the Acteon a posthumous release (Elson 13).

In the second part of The Wits, Kirkman shares a memory of Cox performing at a university, the name of which is not given. Apparently he was "very well esteemed [...] by the Learned, but more particularly by the Butler of one of those Colledges" (Kirkman A3r). This assertion might be supported by the testimony of Antony Wood, a resident of Oxford: "They [the Presbyterians] would not suffer any common players to come into the Universitie, nor scholars to act in privat but what they did by stelth; yet at Act times they would permit dancing the rope, drolles, or monstrous sights to be seen" (Clark 299). This might mean that Cox was allowed to perform at universities; however, no records proving that someone by that name name had visited any such places exists, even if other travelling entertainers are mentioned. Some scholars even claim that Kirkman may refer to a university town and not to the institution itself, making Cox simply a strolling player that travelled across country (Elson 23).

The only places that surely used to host performances of drolls and sketches are the Red Bull theatre, the precincts of Aldgate during Bartholomew fair and public spaces or taverns at Charing Cross and Lincolns-Inn-Fields. The last two of these are only connected with these activities through Kirkman's mention of them on the front-piece of the 1673 edition.

From a contemporary cultural perspective, Shakespeare was probably the greatest playwright of his time in western countries. When, however, one counts the occurrences of Shakespeare's plays in Kirkman's collection of drolls, it becomes quite apparent that Shakespeare is significantly outnumbered by other playwrights, mostly Fletcher and Beaumont. The reasons for this are obvious if we look at the number of the reprints of English dramatic plays published from 1580 to 1660: "Shakespeare wrote nothing as popular as Kyd's Spanish Tragedy, Marlowe's Doctor Faustus, or the anonymous Mucedorus. [...] Shakespeare's most popular plays, in descending order, were apparently Henry IV Part One, Richard III, Pericles, Hamlet, Richard II and Romeo and Juliet" (Taylor 18). All these plays, except for Pericles, were written between 1593 and 1601 - the period when "Marlowe, Kyd and Greene were dead, but Jonson, 
Middleton and Fletcher had not yet replaced them" (18). It is highly probable that only in this time was Shakespeare London's major playwright. Gary Taylor measures Shakespeare's success by the number of plays performed at the royal court during the Christmas season. In 1610, the rivalry between Shakespeare and Fletcher was reaching its peak, with Fletcher's overall dominance after 1619. This dominance and wide popularity of Fletcher lasted for the whole seventeenth century:

Of course, no company would go to the expense of reviving a play unless it had once been popular, and might be popular again. [...] In the 1640s and 1650s, actors trying to defy the parliamentary closure of the theatres reached for Fletcher, not Shakespeare. In London, five different attempts to reopen the theatres between 1647 and 1654 showcased Fletcher. No one was willing to take such risks for a play by Shakespeare. (Taylor 18-19)

Kirkman's collection may function as a confirmation of such claim. The Wits contains only three openly declared adaptations of Shakespeare and one droll that might have been inspired by one of his poetic works. Given the small number of texts, this chapter will briefly describe all of the four pieces in question, focusing mostly on the reasons for choosing these particular parentplays and not others.

By 1642, when the public theatres were officially closed, a long time had passed since the golden age of the Elizabethan theatre and drama. Even though the ban was not as absolute as it might have seemed, the staging tradition had to change completely ${ }^{1}$. The troupes were deprived of their theatres and had to return to the acting and staging typical of the pre-Elizabethan era. "The acting companies reverted to their vagabond heritage, performing what Francis Kirkman called 'pieces of plays', excerpts of the most popular scenes from old reliables" (Taylor 19). It was no longer possible to perform Shakespeare's plays that included shipwrecks, battles or scenes that needed an intricate stage and scenery. Even the ever-famous orchard scene from Romeo and Juliet was difficult to perform in the tavern or at the fairground as there was no other level of the stage except for the ground one. Therefore, amidst the number of Shakespearian characters, a very distinct group of figures emerged - the group of clowns and jesters that were capable of overshadowing the (otherwise strong) appeals of prince Hamlet, King Lear or Coriolanus.

In his Wits, Kirkman lists adaptations of two Shakespearian comedies, one tragedy and one poem, namely Henry IV, Part One, A Midsummer Night's Dream, Hamlet, and Venus and Adonis. In all of these drolls, the parent-plays are greatly shortened and altered; yet the adaptation technique is slightly

\footnotetext{
${ }^{1}$ For more details on how the hypothesis of the non-existent theatre has been challenged, see Willkie (3)
} 
different in each of the cases. In the very first droll of the 1672 edition of The Wits entitled The Bouncing Knight or, The Robbers Rob'd the main focus is on the character of Falstaff, who is referred to as "Jack". The scenes contained in the droll come from the first part of Henry IV, the most popular play by William Shakespeare in that period (Taylor 18). There is no doubt that, even in the time of public and private theatres, the audiences' love for Henry IV was mainly triggered by the figure of Falstaff. Moreover, the title page of the 1598 edition of the play reads "The History of Henry the fourth, with the battell at Shewseburie, betweene the King, and Lord Henry Percy, surnamed Henry Hotspur of the North. With the humorous conceites of Sir John Falstaffe", suggesting the popularity of the comical numbers (Henry IV A1r). The jolly companion of prince Hal was popular to the extent of being actually portrayed on the front piece of Wits, where the reader sees him dancing among many protagonists of sixteenth and seventeenth century English drama: Simpleton, Changling and others. Falstaff is, furthermore, the only Shakespearian character to be incorporated into the engraving, which alone speaks volumes about his significance. The droll is also the very first one in the collection not to have any rules in terms of ordering the drolls - either in alphabetical order or arranged in groups according the authors of the original plays. The first place that had been given to a scene from Henry $I V$ testifies to both the popularity of the character of Falstaff, and to Shakespeare's own, despite the decline in the staging of his plays.

The droll entitled The Bouncing Knight or the Robbers Robed partly adapts the plot of the first part of Henry IV. The anonymous author of the comical sketch chooses only the bits containing the character of Falstaff. Interestingly enough, the second scene of the first act and the second scene of the second act, in which Falstaff and his companions plan to rob (and eventually do so) the travellers, only to be robbed, later on, by Prince Henry, are missing in the adaptation. However, the droll is introduced by a short synopsis, an argument of what happens in the respective scenes:

A company of mad fellowes resolve to take a Purse, and to that purpose separate themselves, 4 in one company, 2 in the other, the four Rob the true men, the two Rob those four again. And then all meeting, the 4 exclame against the absent two, and other Scenes of mirth follow. (Wits 11 )

Such an introduction is quite chaotic, referring to the characters only in terms of numbers, while also calling into question the actual staging of the droll as compared to its publication. If the Bouncing Knight was to be performed, the function of the introductory passage was that of a very simple prologue, presenting the piece to the audience and informing them about the excerpt they were going to see. Or, if the shape of the evening resembled a revue rather than a play, we could think of some "master of ceremonies" who introduced every 
sketch, dance number, song etc. This public commercial genre might have been a very free form of entertainment. According to historical sources, Robert Cox, the only confirmed performer and author of the drolls, employed a boy who was supposed to musically accompany the actor or actors so this form of the performance was indeed rather eclectic, combing all sorts of pastime activities (for example rope dancing, music, and some simple dramatic sketches) (Baker $31)$.

The list of dramatis personae includes eight characters: Prince, Jack, Poines, Peto, Roff, Hostess, Bardol and Drawer. Many of them are, however, called differently in the droll - for example the speeches of Henry $\mathrm{V}$ are assigned to 'Prince' but also to 'Hal'. The spelling of Poines oscillates between "Poines" and "Poynes". "Roff" seems to be a misspelled version of the abbreviated name Rossill. Elson claims that this might have been the name of the actor playing the character of Gadshill (Elson 47). In the Dictionary of Actors one can read that in the 1597 production of Henry IV at the Theatre, Poins says in a speech to the Prince "Falstaff, Harvey, Rossill, and Gadshill shall rob those men that we have already waylaid" (Nungezer 305). Nungezer comments that "in the scene of the robbery (I. ii) the characters here called Harvey and Rossill are discovered to be Bardolph and Peto, which led to Theobald's suggestion that Harvey and Rossill were the actors who took the parts of Bardolph and Peto" (305). On the other hand, A. Gaw admits that Harvey and Rosshill might only be "ghost names" (305). Nevertheless, the droll was certainly inspired by this version of the production and therefore incorporated this name in the text, even though the lines Roff is delivering belong to the character of Gadshill.

Some characters from Shakespeare's play are mentioned in the droll, it is even suggested that they might be on stage, yet they are not listed among the dramatis personae or assigned any lines. This is the case of Harry Percy (Hotspur) - Prince Henry refers to him when talking to Falstaff, who is lying on the ground: "imbowel'd will I see thee by and by, till then, in blood by noble Percy lye" (Wits 1:11). The character of Thomas Percy is also mentioned and a demonstrative "there is Percy" is used, but nothing else suggests that this character did actually appear on stage (12).

Despite the confusing introduction, the adaptation of Henry $I V$, Part 1 is a good example of comic relief during that uneasy period. The author of the reworking specifically chose the passages with the rudest jokes, ignoring the political aspect of the original play. The question, however, remains: Was it possible for the audience to completely overlook the historical context of the parent play? The original drama features stories of revolt against the king, which in the time of beheading Charles I must have been an explosive topic. As previously mentioned, this was Shakespeare's most popular play ever and one can suppose that the late seventeenth-century audience still remembered its plot 
or owned a copy of the play - so the droll, even though it focused on the comical parts of the parent play, might have had political connotations.

The Bouncing Knight contains excerpts from five scenes from Shakespeare's Henry IV, Part I: I.iv; III.iii; IV.ii; V.i and V.iv. The droll opens with Prince Henry saying, "How now Jack, where hast thou been?" and even if the stage direction reads "Enter Several" this scene is entirely dominated by the characters of Prince and Falstaff (Wits 1: 1). This applies to the whole droll occasionally other characters speak too -, but the duo of Falstaff and Prince Hal "steals the show". Some scenes seem to alternate just because Falstaff can thus stay longer onstage. For example, the droll omits lines 273 to 315 from II.iv where the hostess comes and the situation requires Falstaff's exit. However, unlike the original, the droll continues with Prince and Falstaff's witty conversation:

Jack. O no more of that Hal if thou lovest me.

Prince. How long i'st ago Jack since thou saw'st thine own knee. (Wits 1: 5)

Jack's line corresponds with II.iv 272 from the parent play; Prince's utterance is nevertheless line 316 from the same Act. Such cuts and bridges occur regularly in the droll, closely resembling something that we would nowadays call directing and adjusting to the needs of the ensemble. The stage directions are, in fact, considerably more detailed that the ones in Shakespeare. Sometimes the directions inform of costumes and props as in "Enter Jack as to the Wars" (Wits 1: 10). This direction is nowhere to be found in the parent play and, as it is obvious from the subsequent speech that Falstaff is planning to go to war, it must refer to a change in costuming (very simple and minimalistic, given the circumstances described by Kirkman is describing in the preface quoted above). Shakespeare's own stage direction is extended to "Jack in fight falls down as he were dead, the Prince espying him on the ground, speaks" (Wits 1 11). These lines could be either the author of the droll's instructions as to what should happen onstage, or they could mean that this printed version was used by amateur actors, who were not so talented and needed a certain level of guidance.

The droll replaces certain words, especially those relating to Jesus Christ or religion in general, with more neutral expressions. Consider this: in the droll one of Henry's lines goes "Why ye fat paunch, and ye call me, Coward by this light, I'le stab thee" (Wits 1 2). In Shakespeare's original however, the word "Zounds" appears, the abbreviated form of "Christ's wounds", instead of "Why" used in the droll. Henry's former "by the Lord" is equally substituted with "by this light" (Henry IV. Part One II.iv). Such changes can be found throughout the whole droll, usually altering words like "Sblood", "Ifaith" or "Heaven". This suggests a censor's intervention, most probably an instance of self-censorship. Had the droll been officially censored, there would not have 
been any religious references left in the text. Yet, The Bouncing Knight occasionally uses terms such as "pray God" or alike, which rather implies a careless censor from among the droll-performers and authors. There is no evidence that this particular piece was performed, but because it is well-known that a much longer droll such as The Merry Conceited Humours of Bottom the Weaver was staged, one may presuppose that The Bouncing Knight was performed as well (Elson 370).

Gary Taylor sees the existence of the droll The Merry Conceited Humours of Bottom the Weaver from the second volume of the Wits as a sad example of the decline of the English theatrical culture in the seventeenth century. He describes the connection between the original and the droll adaptation as follows: "In the mid-1590s, a hand-picked company of professional actors, performing A Midsummer Night's Dream in their own large London theatre, had demonstrated their confident virtuosity by mocking the incompetence of amateur thespians. By the $1650 \mathrm{~s}$ that dream was in pieces. [...] The mechanicals had taken over" (19-20).

For Taylor the problem lies mainly in the fact that the author of the droll decided to pick only the scenes that featured the "rude mechanicals"; however, a mere a glance at the "Merry Conceited Humours", makes it clear that this is not true. Although the droll indeed works with every scene which introduces Quince's company, it also features several scenes with the fairies, Titania, Oberon, and Puck.

The droll begins with the list of dramatis personae which reveals a lot about the theatrical conventions of the period. The mechanicals, who later transform into the characters of the play-within-the-play Pyramus and Thisbe, were supposed to perform as fairies too. In Kirkman's edition from 1673, the three fairies were supposed to be acted by the performers of Bottom, Flute and Snout. However, such alternation is not possible; in IV.i the fairies enter onstage to help Bottom with scratching his ass's head, forcing the actor portraying Bottom to play two roles at once. Such nonsensical casting is probably a mistake either on the part of Kirkman or of the typesetter and one can imagine that the fairies were performed by Flute, Snout and Snug. The droll also uses the same actor for Titania and "the Dutchess" (meaning Hippolyta) and suggests one performer for the character of Oberon and Duke Theseus. Therefore, The Merry Conceited Humours needs only nine actors to perform the roles of Shakespeare's parent play. Only the quartet of lovers is missing completely, with no traces of their storyline.

The author of the droll does not provide the reader/spectator with the background story of what happened in the original drama prior to the scene that is about to be read/seen. This contrasts with the other Shakespearian drolls that sum up, at least basically, the previous action. The person in charge of the 
adaptation simply added one line to the character of Bottom, who very briefly introduces the circumstances of the scene:

Bottom. Come, Neighbours, let me tell you, and in troth I have spoke like a man in my daies, and hit right too, that if this business do but please his Grace fancy, we are made men for ever.

Quince. I believe so too, Neighbour, but is all our company here? (Wits 2 2930)

Bottom simply presents the conditions of the scene: the artisans are about to do something for the Duke that will make them well-respected and, presumably, rich. In the next few lines one learns that the company of mechanicals is about to rehearse a play: thus, it is not necessary to provide the droll with a lengthy introduction when the explanation for the scenes with the workers is contained in the original work. Even if the audience did not know of Shakespeare's original, the storyline of the mechanical is so simple and so well embedded in the self-explaining lines, that it can function as an autonomous short play.

Apart from the aforementioned change, the scenes with the mechanicals are almost identical to the ones in A Midsummer Night's Dream - the droll uses scenes I.ii, III.i, IV.i and IV.ii, as well as V.i, in which the final performance of Pyramus and Thisbe takes place. Minor changes occur in the scenes with Oberon and Puck (who is, in this edition, referred to as "Pugg") and also Titania and her fairies (II.i; II.ii). This happens mostly because Shakespeare's Oberon often delivers very poetic and lengthy speeches that might have been boring and redundant for the seventeenth century audiences, especially as the drolls were usually performed in some tavern or at a fair.

It is not surprising that the part of The Tragedy of Hamlet, Prince of Denmark, that was used between 1642 and 1660, was the extremely popular gravediggers' scene from Act 5, Scene 1. In the Wits it becomes the Gravemakers Argument. The short introductory note to the droll says: "While he is making the Grave, for a Lady that drown'd herself, Hamlet and his friend interrupt him with Several Questions" (Wits 1 56). No doubt, this works as a marker for the audience members who know who Hamlet is and only need some guidance in the time and dramatic space of the sketch. Indeed, the scene contains many moments when the spectators' knowledge of the characters of Ophelia and Claudius helps a great deal with understanding what is going on. Interestingly enough, one can see that the chosen part and theme of this Shakespearian adaptation differs greatly from the previous two, the humour of the piece being very far from Falstaff and Bottom's jokes. Unfortunately, one might only wonder how the audience reacted to this deeply satirical and even philosophical piece. 
The only visible divergence from the original relates, once again, to the entrances and exits of the characters on stage; this time the adaptation deals with them much more carefully. They are strictly subordinated to the logic of the performance and the actors' needs. For example, Hamlet and Horatio enter the stage in the parent play to be seen during the gravedigger's speech and his song. Nonetheless, such an entrance was certainly not possible under the provisional conditions of the interregnum, when there were no officially accessible big theatre houses with spacious stages. The printed edition of the droll suggests that Hamlet and Horatio enter only after the first gravedigger stops singing: "Grave.: O methought there was nothing a meet. Enter two Gentlemen" (Wits 1: 58). Yet, in the Folio edition, one might find the entrance of the men before the Gravedigger says "Cadgel thy brains no more about it, for your dull ass Will not mend this pace [...]" (Hamlet F1: 5.1). The actors performing the two characters, therefore, enter only when they are about to speak - they do not stand around and watch the gravedigger singing his song.

The droll titled Venus and Adonis, or, the Maid's Philosophy is the shortest of the four Shakespearian adaptations, comprising only 49 lines. This non-comical short scene is of unknown origin, but it is still based on the classical myth of Venus and Adonis. However, "important changes were made to the traditional story, such as the slaying of the young lover by the huntsmen, rather than a wild boar. There is some evidence to suggest that it dates back to the previous century, perhaps as part of a lost full-length play or some longer work" (Scanlon 371). He later discusses the origin of the title of the droll:

The curious subtitle appears in Act III, scene IV of The Dumb Knight (1608) by Gervase Markham and Lewis Machin. One of the characters in the play, after quoting stanza 39 of Shakespeare's Venus and Adonis, is asked about the book he is reading. It is called, he replies, "Maid's Philosophy, or Venus and Adonis". (371)

This mention clearly suggests that the author of the droll knew The Dumb Knight and, consequently, that he was closely acquainted with Shakespeare's poem. Furthermore, as John Elson suggests, the way in which Adonis refers to Venus as "fair nymph" or "dear saint" indeed resembles the traditional Elizabethan romantic conventions of perceiving Venus and Adonis as characters engaged in a romantic relationship; it is, therefore, improbable that the author (or authors) of the adaptation had worked with Ovid or any older classical source when creating a piece inspired by the myth (Elson 394).

The status of Venus and Adonis in the post-Shakespearian society of the seventeenth century was that of a notoriously popular piece. As Kolin puts it "Venus had become mandatory reading for lustful men trying to conquer a young, vulnerable woman" (Kolin 12). Not only Markham and Machin mention 
the poem in their play; in the same year (1608) Middleton's character Harebrain from a play A Mad World, My Masters prevents his wife from reading Venus and Adonis in order not to be cheated on. "Venus's reputation as a seduction manual continued into the middle of the seventeenth century" (Kolin 12). It is, therefore, highly possible that the author of the droll adapted Shakespeare's version -in view of its popularity, but also because of the lewd atmosphere connected with it.

It is hard to produce any summarizing conclusion with regard to the techniques used when adapting William Shakespeare's works. The four examples differ fundamentally in terms of genres, types of humour, and even stage directions required. Therefore, it would not be possible to provide more generalizing points that would describe the position of Shakespeare within Kirkman's collection. What is clear, though, is that even if the position of Shakespearian adaptations within Kirkman's Wits is not the most favourable, being outnumbered by those of Beaumont and Fletcher, those drolls that survived show us that Shakespeare was still considered to be one of the major playwrights of the previous - Elizabethan - period. Given the privileged position of the droll Bouncing Knight and the careful treatment of the parent plays by the authors of the adaptations, it is obvious that the interregnum audience still wanted to see Shakespeare performed and not only read. Gary Taylor says that during the years of civil war and the official closure of the theatres "the mechanical had taken over" (Taylor 20), but that does not seem to be the case. The theatrical means and possibilities simply changed - but the fact that even in those unhappy times of a politically unstable era the public still wanted to entertain themselves with Shakespearian heritage, proves the quality of the playwright. The three Shakespearian clowns, Falstaff, Bottom and the Gravedigger entered the improvised stage of the interregnum to be a comic relief for the people living in uneasy times, and not to diminish Shakespeare's undeniable literary merits.

\section{Works Cited}

Baker, Henry Barton. English Actors from Shakespeare to Macready. New York: H. Holt and Company, 1879. Print.

Clark, Andrew. The Life and Times of Anthony Wood, Antiquary of Oxford, 1632-1695, Described by Himself. I.Oxford: Clarendon Press, 1891. Print.

Cox, Robert. Acteon and Diana. London: Printed for Edward Archer, 1656. Print.

Elson, John James. The Wits, or, Sport upon sport. Ithaca, N.Y.: Cornell UP, 1932. Print.

Goodwin, Gordon. "Francis Kirkman". Dictionary of National Biography, 1885-1900, Volume 31. London: Smith, Elder \& Co., 1892. 219-20. Print.

Kirkman, Francis. The Wits, or, Sport upon Sport in Select Pieces of Drollery (...) London: Printed for Henry Marsh, at the Sign of the Princes Arms in Chancery- 
Lane, 1662. Print.

Kirkman, Francis. The Wits, or, Sport upon Sport Being a Curious Collection of Several Drols and Farces (...). London: Printed for Fran. Kirkman, and are to be sold by most book-sellers, 1673. Print.

Kolin, Phillip C. Venus and Adonis. Critical Essays. New York: Garland Publishing, 1997. Print.

Nungezer, Edwin. A Dictionary of Actors and Other Persons Associated with the Public Representation of Plays in England before 1642. Ithaca, N.Y.: 1929. Print.

Plomer, Henry Robert. A Dictionary of the Booksellers and Printers, 1641-1667. London: Bibliographical Society, 1907. Print.

Randall, Dale B.J. Winter Fruit: English Drama 1642-1660. Lexington: The University Press of Kentucky, 1995. Print.

Rollins, Hyder E. "A Contribution to the History of the English Commonwealth Drama". Studies in Philology. 18, 3. Chapel Hill: University of North Carolina Press, 1921. 267-333. JSTOR. Feb 20 2017. Web.

Scanlon, Paul A. The Common Touch: Popular Literature from the Elizabethans to the Restoration. Volume 1. Cambridge: Cambridge Scholars Publishing, 2014. Print.

Shakespeare, William, and A. R. Humpreys. King Henry IV, Pt. 1. London: Routledge, 1996. Print.

Shakespeare, William, and Harold Jenkins. Hamlet. London: Routledge, 1982. Print.

Taylor, Gary. "Shakespeare Plays on Renaissance Stages" in The Cambridge Companion to Shakespeare on Stage. Eds. Stanley Wells and Sarah Stanton. Cambridge: Cambridge UP, 2002. 1-20. Print.

Willkie, Rachel. Staging the Revolution. Drama, Reinvention and History, 1647-72. Manchester: Manchester UP, 2015. Print.

Mercurius Democritus. 22 - 29 June 1653. 467. Print. 